\title{
Improved Learning Outcomes of Sociology Subject of Social Interaction (Advertising) in Class X Students of State Senior High School 3 Sungguminasa Gowa
}

\author{
Sulvahrul Amin ${ }^{1}$, Maria Ulviani ${ }^{2}$ \\ 1,2 Universitas Muhamamdiyah Makassar, Makassar, Indonesia
}

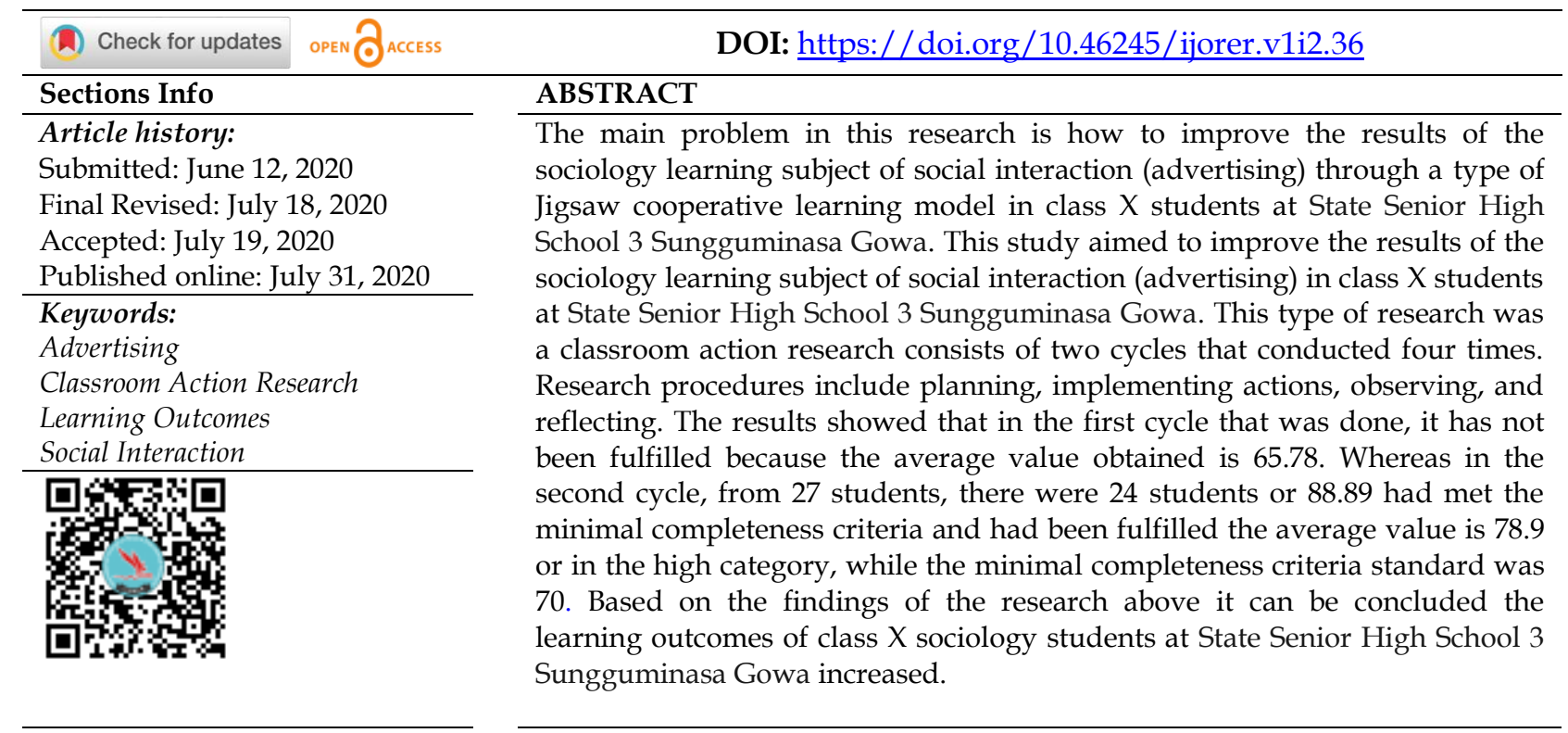

\section{INTRODUCTION}

Success in the learning process is inseparable from the readiness of students and the readiness of teachers (Agustini, 2015; Ariyanti, 2015; Desyana \& Sabirin, 2017; Dodi et al., 2015). Students are required to have an interest in the lessons learned such as sociology, as well as the instructor is required to master the material to be taught and be able to choose the right learning model so that it will create good educational interactions leading to improved sociological learning outcomes because until now sociology learning outcomes considered to be still low, whereas sociology as a branch of Science has an important role in increasing the mastery of science and technology. Learning sociology in schools is fairly complicated and difficult for students to understand. Sociology is a branch of science that understands social life and is still very young, but until now Indonesia is still very much concerned with the classic problem, in this case, namely the quality of education.

The reality on the ground shows that student learning outcomes in sociology subjects are quite low compared to other subjects. Learning sociology in schools is also intended to provide separate motivation for students to learn and better understand how to interact in the school environment and the community and forms of social interaction. In sociology, almost all aspects of community life are discussed, where we know that the object of the study of sociology in society, which is seen from human relations in the process arising from human relations in society or social processes that occur in the community, namely social interaction. Given the importance of the role of sociology, 
especially social interaction, and is a science that is applied at every level of education and even higher education. However, it did not provide significant results that student achievement in sociology subject matter of social interaction was increasing. Then there needs to be an effort in improving student learning achievement (Farimah \& Zohreh, 2016; Habib, 2015; Irma, 2015)

Based on preliminary observations carried out in class X State Senior High School 3 Sungguminasa Gowa found that the student learning activities are still low or lack. This is influenced by low student motivation. The lack of active students in learning sociology is caused by the lack of students' understanding of the benefits of learning sociology and its role in life in the future. This causes students to only come, sit, be quiet, and listen so that the odd semester exam results (1) in the 2012-2013 academic year are on average (65). Whereas from the grade $X$ students at State Senior High School 3 Sungguminasa Gowa, there are only 9 students who have the learning outcomes meet the minimal completeness criteria. On average students can only achieve a score 65, while the minimal completeness criteria standard is 70 . This condition causes student achievement to not show significant improvement. The low student learning outcomes, especially sociology caused by the learning model and the methods used by the teacher are still less effective so that there is a tendency for teacher-centered teaching while students are not allowed to think about and find their concepts, students are less skilled in solving problems and tend to be passive in learning activities.

One model that according to researchers needs to be encouraged is the Jigsaw type cooperative learning model. Jigsaw included in the form of learning full class learning. This activity is a way that can help students stay focused and ready to be alert in various learning situations that are happening (Mawardi, 2015; Syukur, 2016; Ramadhan, 2019). In this activity, jigsaw forms small groups that are responsible for explaining learning material, almost the same as the learning team model, but in Jigsaw, there is no exchange of team members. The focus examined in the conduct of this study were:

1. The learning process, namely the application of the learning process with a jigsaw cooperative learning model

2. Learning outcomes, namely student learning outcomes obtained from the evaluation of learning outcomes after participating in sociology learning activities that are measured based on learning objectives.

\section{RESEARCH METHOD}

This research is a classroom action research. The study consisted of a series of cycles, each cycle consisting of 4 stages namely planning, implementing, observing, and reflecting. This study was conducted in July to September 2016-2017 school year (odd semester). This research was conducted at State Senior High School 3 Sungguminasa Gowa. The subjects in this study were class X students at State Senior High School 3 Sungguminasa Gowa were 27 students, consisting of 12 males and 15 females with heterogeneous socioeconomic backgrounds. This research was a classroom action research that carried out in two cycles, namely the first cycle and the second cycle. The general description of each cycle was: Planning, implementing, observing, and reflecting. 
To obtain this research data, a research instrument in the form of a test in the form of sociology learning outcomes were interview guidelines and a questionnaire. Tests in the form of student sociology learning outcomes essays are made at the end of each cycle to measure the extent of students' understanding of the material being taught, tests in the form of essay questions, interview guidelines, namely a list of questions in conducting a question and answer with the informant to get the information needed, and the questionnaire were used to find out students' responses regarding the implementation of the action. As for Data collection techniques were as follows: (1) Data regarding the conditions of teaching and learning activities and changes in attitudes of students and teachers were collected through observations as learning activities take place. (2) Data about student learning outcomes were collected using essay tests at the end of each cycle. (3) Data about student responses were obtained by giving a questionnaire.

Student learning outcomes data in the form of tests in the form of essays will be analyzed using scores based on benchmark reference assessments, calculated based on the maximum score possible by students. The values obtained were grouped into five categories: very high, high, medium, low, and very low. The criteria used to determine the categories of sociology learning outcomes were based on standard categorization techniques established by the Ministry of National Education as in the following Table 1

Table 1. Standard category techniques based on the ministry of national education decrees.

\begin{tabular}{cc}
\hline Score & Category \\
\hline $0-54$ & Very low \\
$55-64$ & Low \\
$65-69$ & Is \\
$70-89$ & High \\
$90-100$ & Very high \\
\hline
\end{tabular}

An indicator of the success of this class action research if there was an increase in the average score of students' sociology learning outcomes after the jigsaw type cooperative learning model is applied, and the treatment was considered successful if a minimum of $85 \%$ of students achieves minimal completeness criteria with a score of 70 of the score an ideal that might have been 100 .

\section{RESEARCH RESULTS AND DISCUSSION}

This section will discuss the results of research on improving sociology learning outcomes through a Jigsaw type cooperative learning model subject to social interaction (advertising) on students class $X$ at State Senior High School 3 Sungguminasa Gowa from cycle I to cycle II using qualitative analysis that is data about observations, while data about student learning outcomes are analyzed quantitatively using descriptive statistics namely average scores, standard deviations, frequencies, and the lowest percentage percentages and grades the highest students reach each cycle. Researchers examined the improvement of sociology learning outcomes through a cooperative learning model type of jigsaw subject of social interaction (advertising) on student class $X$ at State Senior High School 3 Sungguminasa Gowa by applying classroom action research. In this study through two cycles, each cycle consisting of 4 meetings, the time at each meeting was $2 \times 45$ minutes. The discussion of each cycle is as follows: 


\section{Cycle I Data Exposure}

Cycle I was held for four meetings, namely $8 \times 45$ minutes ( 3 meetings for the implementation of actions and 1 meeting for giving daily tests). The material is taught about social interaction using four stages, namely: planning, implementation, observation, and reflection. The learning process carried out in the first cycle, namely:

- At the first meeting, the teacher said that the learning strategy used during this study was a jigsaw cooperative learning model.

- The teacher starts the lesson by conveying the material to be learned, the learning objectives, and providing motivation for students to take the lesson seriously.

- The teacher starts the learning activity by raising a problem with the material being discussed using a jigsaw cooperative learning model and asking students to work in groups. If students' knowledge is not enough to answer the problem, the teacher guides students towards the right and correct answers or explains material that is not understood by students.

- The teacher gives follow-up questions then students conclude the answers of other students and students must mutually express their opinions from the questions given by the teacher. The teacher always monitors the learning process of students, to find out whether the material provided is understood.

- Students are allowed to ask questions and ask for explanations from the teacher.

- To strengthen students' understanding of teaching materials provided by the teacher, students are directed to work on the practice questions.

- At the end of the meeting, the teacher gives homework to be done individually.

As an evaluation material, observations are made on student activities during the teaching and learning process and are recorded on the student observation sheet. Based on the implementation of the method, it shows that the action in the first cycle is not shown optimal. At the beginning of this first cycle, especially at meeting 1 , the actions taken have not shown any significant changes. Generally, students have not been able to follow the teaching and learning process well. This can be seen from the lack of students who are active in the learning process. At the beginning of the first cycle of teaching, students' attention to the subject matter when teaching and learning activities are taking place is still lacking. Generally, students only listen and do as instructed by the teacher, even though they don't understand (Jayanti, 2016; Judi, 2012). This is indicated by the lack of students asking questions and responding to the subject matter being taught. Besides, students who dare to appear in front of the class to complete assignments with the type of jigsaw cooperative learning model given are still limited to students who are classified as smart. The lack of students who are active in the teaching and learning process is largely due to their low interest in learning sociology. Part of it is caused by the way teachers teach which sometimes makes it difficult for them to understand the teaching material presented even though the type of cooperative learning model jigsaw has begun to be applied but student learning interest is still low. In the second week, according to observations, it was seen that students' efforts to be active in the learning process and students who did the exercises then read them in front of the class but still asked for the teacher's guidance. Based on the results obtained during the first cycle, which have not shown maximum results, the researchers decided to proceed to the next cycle. 


\section{Cycle II Data Exposure}

The implementation of the second cycle of action was relatively the same as the implementation of the action in the first cycle. The implementation was carried out improvements from the first cycle so that learning outcomes increase. This cycle was carried out for four meetings ( $8 \times 45$ minutes).

As explained earlier, the second cycle lasted for 4 meetings ( 3 meetings for implementation of actions and 1 meeting for daily tests). The material taught in cycle II is Social Problems. The steps in the second cycle are the same as those in the first cycle, the steps with the type of jigsaw cooperative learning model are still carried out by doing some development and repairing the problems found. After improving the results of the actions in the teaching and learning process in the first cycle, several improvements were made, namely:

- The teacher starts the lesson after the classroom atmosphere is conducive and students are ready to learn so that students are more focused on the material to be learned. The teacher gives direction so that all activities outside of sociology learning are stopped first and prepare everything needed for the material to be learned.

- The teacher motivates students to dare to ask questions and dare to appear in front of the class presenting learning outcomes. The teacher informs that the courage and craft of students is one of the aspects assessed by the teacher.

- The teacher has more control over the activities of students in learning and trying as much as possible.

- The teacher extends the practice questions and homework to further deepen students' understanding of the material they have learned.

Entering the second cycle of the teaching and learning process that took place at the beginning of the meeting is still not much different from the third meeting in the first cycle, but because students continue to be motivated finally students begin to be active in each subject matter given. During the process of teaching and learning, students who are active in the learning process continues to grow as well as students who are active in presenting the results of learning to answer questions from practice questions given to be read in front of the class. While working on the practice questions given, students generally have to do it by their selves; even there are already some active students to submit their opinions about the learning material. They began to realize that teacher research is not only on the final exam but also on student activities during the teaching and learning process (Lestari, et al., 2016; Mardiah, 2018; Merita, 2014). In general, students are accustomed to and increasingly like the process of teaching and learning through Jigsaw cooperative learning models. The following data were obtained during the second cycle of being covered (3 meetings).

Table 2. Observation results student activity student class X State Senior High School 3 Sungguminasa Gowa in cycle II.

\begin{tabular}{|c|c|c|c|c|c|c|}
\hline \multirow{2}{*}{ Component observed } & \multicolumn{6}{|c|}{ Cycle II } \\
\hline & I & II & III & VI & Average & $\%$ \\
\hline $\begin{array}{l}\text { The number of students presents during the learning process } \\
\text { takes place. }\end{array}$ & 25 & 25 & 26 & 27 & 25.7 & 95.4 \\
\hline Students who pay attention to the teacher's explanation. & 24 & 23 & 25 & C & 24 & 88.9 \\
\hline $\begin{array}{l}\text { Students who carry out other activities when discussing learning } \\
\text { material. }\end{array}$ & 4 & 2 & 1 & $\begin{array}{l}\text { Y } \\
\text { C } \\
\mathrm{L}\end{array}$ & 2.3 & 8.6 \\
\hline Students who are active in the learning process. & 19 & 22 & 24 & E & 21.7 & 80.4 \\
\hline
\end{tabular}




\begin{tabular}{|c|c|c|c|c|c|c|}
\hline \multirow{2}{*}{ Component observed } & \multicolumn{6}{|c|}{ Cycle II } \\
\hline & I & II & III & VI & Average & $\%$ \\
\hline Students who are active in presenting learning outcomes & 12 & 13 & 17 & II & 14 & 51.8 \\
\hline Students submit opinions & 7 & 11 & 15 & $\mathrm{E}$ & 11 & 40.7 \\
\hline Students who still need guidance & 6 & 4 & 3 & $\mathrm{~s}$ & 4.3 & 15.9 \\
\hline Students who are still passive & 6 & 3 & 2 & $\mathrm{~T}$ & 3.7 & 13.6 \\
\hline
\end{tabular}

If the results of the above observations are compared with the results of the above observations compared with the results of observations in the first cycle, then obtained some information, namely:

- Students who were present during the learning process took place in the first cycle were 98 students or $90.7 \%$ and in the second cycle were 103 students or $95.4 \%$.

- Students who pay attention during the learning process took place in the first cycle were 48 students or $60.4 \%$ and in the second cycle were 72 students or $88.9 \%$.

- Students who did other activities during the discussion of learning material in the first cycle were 13 students or $15.9 \%$ and in the second cycle, there were 7 students or $8.6 \%$.

- Students who were active in the learning process in the first cycle were 46 students or $56.8 \%$ and in the second cycle, there were 65 students or $80.4 \%$.

- Students who were active in presenting learning outcomes in the first cycle were 29 students or $35.9 \%$ and in the second cycle, there were 42 students or $51.8 \%$.

- Students submitted opinions in the first cycle of 19 students or $23.3 \%$ and the second cycle was 33 students or $40.7 \%$.

- Students who still need guidance in the first cycle are 24 students or $29.6 \%$ and in the second cycle there are 13 students or $15.9 \%$

- Students who are still passive in the first cycle were 25 students or $30.7 \%$ and in the second cycle, there were 11 students or $13.6 \%$.

Based on the above results, in general, it can be said that the activities in cycle II have increased learning outcomes compared to cycle I. at the end of cycle II students are given tests or tests to test students' abilities, while still tightening supervision as described in quantitative analysis and analysis Qualitatively, the results obtained by students in cycle II have increased compared to cycle I. From the results of quantitative analysis and qualitative analysis above, it can be concluded that after the implementation of the learning process through the cooperative learning model of listening team type, there was an increase in learning outcomes such as active students in the class, diligent, confident appearing in front of the class, and student motivation.

\section{Student Reflection}

From the results of the analysis of student reflections or responses, it can be concluded into the following categories:

- Student Opinions on Sociology Lessons

After evaluating by researchers during the process of teaching and learning activities in general students are interested in sociology lessons, according to them, sociology lessons are one of the very important lessons to be learned because they are useful in daily life or other fields. But it is also undeniable that some students think that sociology is a difficult subject and those who argue that sociology is difficult. Some students argue that sociology requires a lot of memorization. Another reason that arises 
so like sociology is that students are happy with teaching researchers who are considered more relaxed and explain the subject matter by the social context,

- Student opinion on the type of jigsaw cooperative learning model.

In general, students think that teaching sociology by using a cooperative learning model jigsaw type subject of social interaction is very helpful for them to better understand the concept of social interaction because by giving assignments both individually and in groups students can exchange opinions about what they know about the subject matter being studied. Also, they can use their time effectively even more so on each responsibility the results of their discussion can exchange opinions.

Based on the results of the research that has been analyzed, it can be seen that the results of tests in the form of essays that have been given to students after using the Jigsaw type cooperative learning model to increase learning outcomes on the subject of social interaction have increased. This can be seen from the increase in the average value of students during this study, this means that the applied model can deliver student learning outcomes more effectively, and reduce students who get low scores. The average value of student learning outcomes if converted into a four-scale categorization is in the medium category which at first was in a low category. This shows that the results of learning sociology students increased. In the first cycle during the learning activities, students were still less motivated to take lessons because the learning model provided was new and unique in their view, even though students felt awkward about the learning model provided (Pratiwi, 2014; Pratiwi, 2015; Roberto, 2015; Roberto, 2015; $\mathrm{Wu} \& \mathrm{Hu}, 2017)$. So as if this cycle I orientation is students recognize the learning model that is applied and the teacher knows the individual character and class characters of students. After reflection in the first cycle, activities that are deemed necessary to improve student learning outcomes in cycle II show that student motivation has increased. At first, they only wrote what was in the book, after entering cycle II students were able to develop the material with their group members. After being given the final test of cycle II, the average score achieved by students is in the high category when compared to the final test in cycle I.

Besides the increase in student sociology learning outcomes during the study from cycle I to cycle II, several changes have occurred in student attitudes. These changes are qualitative data obtained from the observation sheet at each meeting recorded by the teacher during the study. It was also observed by researchers in this second cycle that the atmosphere of learning and a sense of togetherness that grows and develops among group members allows students to understand and understand the subject matter better, and students who are less passionate about learning will be assisted by other students who have higher learning enthusiasm and can apply what he has learned. So they are easier to master and have no trouble when given a test or test in the form of an essay. So, this data reinforces the previous data, which is an increase in the number of students who can do the given task.

\section{CONCLUSIONS}

Based on the results and discussion, in cycles I and II it can be concluded that the application of a jigsaw cooperative learning model can improve the sociological learning outcomes of the subjects of class X at State Senior High School 3 Sungguminasa Gowa. An increase in sociology learning outcomes of class X students at State Senior High School 3 Sungguminasa Gowa, after the Jigsaw cooperative learning model, was 
applied. An increase in the percentage of activities in the form of; student attendance, students who ask about material that was not yet understood, students who did homework, students who were active when studying groups, and students who responded to other group presentations. In the first cycle, 9 students completed or $33.33 \%$ with an average score of 65.78 , and in the second cycle increased by 24 or $88.89 \%$ with an average value of 78.9. The application of the Jigsaw cooperative learning model can improve student learning outcomes in the teaching and learning process, this can be seen from the enthusiasm of students learning, student activity in discussions and the process of socialization among students running smoothly and the value of students has increased. Suggestions that the authors can put forward in connection with the results of this study were as follows: (1) It is better to apply the jigsaw cooperative learning model in sociology learning. The teacher can adjust the learning material that was suitable so that students do not feel bored and bored because learning strategies were increasingly varied. (2) The teacher should provide opportunities and freedom for students to express and be creative in the learning process. It was expected that teaching staff in the field of study, especially in the field of sociology, will apply appropriate learning strategies in teaching each subject so that learning objectives can be achieved

\section{REFERENCES}

Agustini, I.M.N. (2015). Teaching speaking through substitution drills to the seventh grade students of SMP N 3 Gianyar academic year 2014/2015. Jurnal Pendidikan, 1(1), 7-8.

Ariyanti, P. (2015). Penerapan media pembelajarean film untuk meningkatkan keaktifan dan hasil belajar pada mata pelajaran bahasa inggris di SMA Negeri 2 Surakarta tahun ajaran 2014/2015. Jurnal Pendidikan UNS, 4(1), 1-8.

Desyana, M., \& Sabirin, M. (2017). Efektivitas model pembelajaran ARIAS pada materi penjumlahan dan pengurangan bilangan bulat. Jurnal Tarbiyah, 6(1), 41-52.

Dodi, M., \& Yulia, M. (2015). Penggunaan film berbahasa Inggris dengan english subtitle dalam meningkatkan keterampilan listening. Journal of University Research Coloiqium, 2(2), 140-147.

Farimah, G., \& Nafissi, Z. (2016). The effect of using english captions on Iranian EFL student's listening comprehension. Procedia Social and Behavioural Science Journal, 6(4), 105-112.

Habib, G. (2015). Investigating the effect of video captioning on listening comprehension. Procedia Social and Behavioural Studies Journal, 2(9), 205-212.

Irma. (2015). Penerapan strategi LRD untuk meningkatkan hasil belajar bahasa indonesia kelas V. Jurnal PGSD, 12(1): 22-23.

Jayanti. (2016). The use of listen-read-discuss (L-D-R) strategy to improve reading comprehension (classroom action research of the eighth grade students of SMPN 3 salatiga in the academic year of 2015/2016. Graduating Paper STAIN Salatiga, 4(3): 89-90.

Judi, B. (2012). Listening: Attitudes, principles, and skills. New York: Roultledege Press.

Lestari, A., Nursalam dan Mardhiah. (2016). Pengaruh model pembelajaran ARIAS (assurance, relevance, interest, assesment, satisfication) terhadap hasil belajar matematika siswa kelas VII SMPN 1 Sungguminasa Kab. Gowa". Jurnal Matematika dan Pembelajaran (Mapan), 5(1), 110-124. 
Mardiah, A. (2018). Penggunaan media film untuk meningkatkan hasil belajar pada mata pelajaran bahasa Indonesia. Jurnal Pendidikan, 12(2), 19-27.

Mawardi. (2015). Peningkatan Aktivitas Belajar Mahasiswa Dengan Metode Jigsaw. PIONIR: Jurnal Pendidikan, 3(1), 1-17.

Merita, I. (2014). The effectiveness of using movies in EFL classroom. Academic Journal of Interdisciplinary Studies, 2(6), 121-132.

Pratiwi, Y. (2014). Pelaksanaan model pembelajaran ARIAS terintegrasi PBI di kelas X SMA negeri 5 Surakarta tahun pelajaran 2013/2014. Jurnal Pendidikan UNS, 3(2), 50-58.

Pratiwi, Y. (2015). Pelaksanaan strategi listen, read dan discuss di kelas X SMA Negeri 5 Surakarta tahun pelajaran 2014/2015. Jurnal Pendidikan UNS, 3(2), 50-58.

Ramadhan, T. (2019). Peningkatan hasil belajar mawaris melalui pembelajaran kooperatif tipe Jigsaw. DAYAH: Journal of Islamic Education, 2(2), 230-250.

Roberto, L.C.R. (2015). The pros and cons of learning from the teacher's standpoint. Journal of University Teaching E Learning Practice, 3(1), 1-19.

Syukur, H. (2016). Building up students' speaking achievement through jigsaw technique. Jurnal Adabiyah, 16(2), 122-137.

$\mathrm{Wu}, \mathrm{H} ., \mathrm{Y} \mathrm{Hu}$, \& Ping. (2017). Major factors influencing reading comprehension. Sino-Us English Teaching Journal. 4(9), 14-19.

\section{* Sulvahrul Amin (Corresponding Author)}

Muhammadiyah University Makassar, Makassar, Indonesia

Jl. Sultan Alauddin No.259, Gn. Sari, Kec. Rappocini, Kota Makassar, Sulawesi Selatan 90221, Indonesia

Email: sulvahrul@unismuh.ac.id

\section{Maria Ulviani}

Muhammadiyah University Makassar, Makassar, Indonesia

Jl. Sultan Alauddin No.259, Gn. Sari, Kec. Rappocini, Kota Makassar, Sulawesi Selatan 90221, Indonesia

Email: mariaulviani@unismuh.ac.id 